\title{
Study Activity Study Focus Indicator
}

National Cancer Institute

\section{Source}

National Cancer Institute. Study Activity Study Focus Indicator. NCI Thesaurus. Code C94083.

Specifies whether the activity is a key investig ational activity for a study. 